\title{
Prolongation of rat corneal graft survival by treatment with anti-CD4 monoclonal antibody
}

\author{
W Ayliffe, Y Alam, E B Bell, D McLeod, I V Hutchinson
}

\begin{abstract}
A rat model of orthotopic corneal graft rejection was used to investigate the effect of depletion of subpopulations of immune cells by treatment with monoclonal antibodies. Though $\mathrm{CD4}^{+}$cells were not eliminated completely by anti-CD4 monoclonal antibodies there was a profound delay in the rejection times of orthotopic corneal allografts. Furthermore a third of the $\mathrm{CD4}^{+}$depleted animals failed to reject corneal allografts by 100 days post grafting. Despite an almost complete depletion of circulating $\mathrm{CD8}^{+}$cells, the anti-CD8 antibody treated animals rejected corneal allografts in a similar time course to allografted controls treated with a non-reactive control antibody OX21. These results demonstrate that $\mathrm{CD8}^{+}$ $T$-cells are not required for rejection of corneal allografts whereas $\mathrm{CD4}^{+} \mathrm{T}$-cells play a critical role in the rejection response. Treatment with anti-CD4 antibodies may have a useful clinical application.
\end{abstract}

(BrF Ophthalmol 1992; 76: 602-606)

Human corneal grafts are not rejected in the majority of recipients unlike allografts of most other organs, and this lower susceptibility to rejection is termed 'immunological privilege'. ${ }^{1}$ However privilege is relative and corneal grafts in eyes that have suffered inflammation have a high failure rate. ${ }^{2}$ The main cause of graft failure is immunological rejection ${ }^{3}$ but the mechanisms of corneal graft rejection are poorly understood. It has been proposed that $\mathrm{CD}^{+}{ }^{+} \mathrm{T}$-helper cells, $\mathrm{CD}^{+} \mathrm{T}$-cytotoxic cells, and inflammatory cells are involved in solid organ graft rejection. ${ }^{4}$ Though recognition of foreign antigens via the afferent limb of the immune system by specific T-cells is important in mediating corneal graft failure $^{5}$ the precise effector mechanism is unknown. There is little direct evidence to support the role of cytotoxic $\mathrm{CD}^{+} \mathrm{T}$-cells as the effector cells of corneal graft rejection, though anti-donor splenic $\mathrm{CD}^{+} \mathrm{T}$-cells have been generated in vivo from corneal grafted animals. ${ }^{6}$ However the association of a particular in vitro immune response with graft rejection does not necessarily imply that it is a requirement for rejection.

It would seem from observations of the rejection of other organs that the $\mathrm{CD}^{+}{ }^{+} \mathrm{T}$-cell plays a critical role in allograft rejection, whereas the $\mathrm{CD}^{+} \mathrm{T}$-cell does not. ${ }^{8-10}$ Indirect evidence derived from immunohistochemical analysis of cells infiltrating rejecting corneal allografts in rats failed to identify significant infiltration by $\mathrm{CD}^{+}$cells though a heavy infiltration of macrophages was identified." 12 That $\mathrm{CD}^{+}$cells are neither necessary nor sufficient to cause corneal graft rejection in mice was recently suggested by depletion experiments in mice. ${ }^{13} \mathrm{We}$ studied the survival of corneal allografts in adult euthymic rats depleted of either $\mathrm{CD}^{+}$or $\mathrm{CD}^{+}$cells and prolonged by regular monoclonal antibody (mAb) therapy. We found that the rat corneal allograft rejection response was not affected by profound $\mathrm{CD}^{+}$depletion whereas even only partial $\mathrm{CD}^{+}$depletion led to delayed rejection or indefinite survival.

\section{Materials and methods}

ANIMALS

Inbred male DA $\left(\mathrm{RT}^{\mathrm{a}}\right)$ and Lewis $\left(\mathrm{RT}^{\mathrm{I}}\right)$ rats aged 8-14 weeks were obtained from Manchester University Medical School Animal unit. BALB/c mice aged 6-8 weeks were bred in the same unit.

\section{CORNEAL TRANSPLANTATION}

Lewis strain donor rats were killed by cervical dislocation and $3 \mathrm{~mm}$ central corneal discs were scored by trephine. The removal was completed with corneoscleral scissors and the button, covered by balanced salt solution, was left in situ until required in order to minimise endothelial damage caused by excessive manipulation.

The technique used throughout the study was a modification of that described by Coster ${ }^{14}$ and allowed retention of a non-irritant single suture with a buried knot. Recipient DA rats were anaesthetised with ether and $0.2 \mathrm{ml}$ of diazepam solution $(2 \mathrm{mg} / \mathrm{l})$ was injected intraperitoneally. The right eye was anaesthetised with a drop of benoxinate $0.4 \%$ before a $3 \mathrm{~mm}$ trephine marked the recipient bed. The button was removed with microforceps and corneoscleral scissors. The prepared donor button was carefully manipulated into the bed and secured with 8-10 bites of a continuous 10/0 monofilament nylon suture placed intrastromally and tied into the wound with a triplicate knot cut flush to the surface. A single drop of chloramphenicol $0.5 \%$ was instilled.

\section{POSTOPERATIVE MANAGEMENT}

Animals were examined on the first postoperative day; those with surgical failures due to wound dehiscence, iris prolapse, and hyphaema were excluded from the study and killed. The remaining animals received a drop of chloramphenicol and were thereafter examined on alternate days. On day 3 postoperatively any opaque grafts were eliminated from the study because they were more likely to represent excessive mechanical damage to the donor

University Department of
Ophthalmology,
Manchester Royal Eye
Hospital, Oxford Road,
Manchester
W Ayliffe
D McLeod
Immunology Group,
Department of Cell and
Structural Biology,
Stopford Building,
University of
Manchester
W Ayliffe
Y Alam
E B Bell
I V Hutchinson
Correspondence to:
Mr W Ayliffe, FRCS
FCOphth, Manchester Royal
Eye Hospital, Oxford Road,
Manchester M13 9WH.
Accepted for publication
23 April 1992


material rather than immunological rejection. A final drop of chloramphenicol was then instilled.

\section{CLINICAL OBSERVATION}

Grafted animals were examined under anaesthesia on alternate days using a portable slitlamp. The grafts were graded from $0-4$ for opacity, oedema, and vascularity as previously described. ${ }^{12}$ The day of rejection was recorded as that on which the combined score reached 6 or more.

\section{STATISTICAL ANALYSIS}

The survival times from transplantation until rejection were compared using the Mann Whitney test.

\section{MONOCLONAL ANTIBODIES (mAb)}

Ascites fluid from BALB/c mice injected with one of the following monoclonal producing hybridoma cell lines was collected in this laboratory: anti-CD4 (W3/25, OX35, OX38), anti-CD8 (OX8), anti-alpha/beta T-cell receptor (R73) (a kind gift of Professor Thomas Hunig, Würzburg). Radial immunodiffusion assays were used to estimate the immunoglobin (Ig) concentrations. For injection mAbs were diluted in phosphate buffered saline (PBS) and stored at $-70^{\circ} \mathrm{C}$ in $1 \mathrm{ml}$ aliquots.

\section{CELLULAR DEPLETION IN VIVO}

DA rats aged $10-12$ weeks old received intraperitoneal injections of $1 \mathrm{ml}$ of ascites containing $6 \mathrm{mg}$ of OX8 (anti-CD8) mAb three times a week. A second group was treated three times a week with $1 \mathrm{ml}$ of a cocktail containing two noncompeting anti-CD4 mAbs, OX $35(0.75 \mathrm{mg})$ and OX38 $(2.5 \mathrm{mg})$ which deplete $\mathrm{CD}^{+}{ }^{+} \mathrm{T}_{\text {-cells. }}{ }^{15}$ The third group was injected three times a week with $1 \mathrm{ml}$ of a non-reactive control $\mathrm{mAb}$ OX21 (anti-human C3b) that does not react with rat antigens. Treatment was continued for 48 days. On day 16 after the initial injection of $\mathrm{mAb}$ the animals received a penetrating allogeneic Lewis corneal graft into the right eye.

\section{MONITORING OF DEPLETION}

The ability of the antibody injections to deplete circulating cells was monitored at 7-10 day intervals by flow cytometry. Blood samples of 1 $\mathrm{ml}$ were obtained from the tail vein of each $\mathrm{CD} 8^{-}$ and $\mathrm{CD}^{-}$depleted rat. After separation of leucocytes on a Ficoll density gradient (specific gravity 1.083), cells were washed and surface phenotyped. Leucocytes from the anti-CD8 treated rats were stained using a primary mouse anti-CD8 $\mathrm{mAb}(\mathrm{OX} 8)$ followed by fluorescein conjugated FITC-F $\left(\mathrm{ab}^{1}\right)_{2}$ rabbit anti-mouse IgG, which fluoresces green (Dako Ltd, High Wycombe, UK), containing $1 \%$ normal rat serum to block anti-rat Ig cross-reactivity. Leucocytes prepared from the anti-CD4 treated rats were double stained using a five-stage staining protocol (1) mAb R73 (anti-T-cell receptor); (2) FITC-F $\left(\mathrm{ab}^{\prime}\right)_{2}$ anti-mouse IgG in $1 \%$ normal rat serum; (3) blocked with W6/32 (mouse mAb non-reactive with rat); (4) biotinylated anti-CD4 mAb (b-W3/25); (5) phycoerythrin-streptavidin, which fluoresces red. Cells were held on ice and washed at each stage with PBS containing $2 \%$ fetal calf serum plus $0.02 \mathrm{M}$ sodium azide to prevent capping of surface molecules, and finally fixed in $1 \%$ formaldehyde for flow cytometric analysis using the Beckton Dickinson FACS cell sorter. Using an optical to electronic coupling system, the flow cytometer records how the cell interacts with a laser beam in terms of the ability of the cell to scatter the incident light and to emit fluorescence. Dead cells and cell debris were excluded by electronic gating on forward and side angle light scatter. Analysis of $10^{+}$events was performed using the Consort 30 program.

\section{IMMUNOHISTOCHEMISTRY}

Corneoscleral buttons were removed and immediately frozen in liquid nitrogen. Serial sections of $5 \mu \mathrm{m}$ thickness were cut across the central area of the graft and stained using an indirect immunoperoxidase technique. Normal rabbit serum was added to the sections to block non-specific antibody binding prior to $\mathrm{mAb}$ incubation. A panel of mouse mAbs (produced as supernatants of hybridoma cell cultures in this laboratory) was used: W3/25, OX8, R73, OX1 (anti-CD45, the leucocyte common antigen) or OX42 (anti-macrophage). Rabbit anti-mouse peroxidase conjugated secondary antibody (Dako Ltd) was added before development in diaminobenzidine and hydrogen peroxide and slides were counterstained with $50 \%$ haematoxylin solution.

A non-reactive culture supernatant (OX21) was applied to sections as a negative control and sections of normal rat spleen were used as a positive control.

Slides were examined by the same observer in a masked fashion on three separate occasions. Cell numbers were estimated in the mid stroma of the centre of the graft using a $\times 40$ power objective and $\times 12.5$ eye piece graticule.

\section{Results}

\section{CELL DEPLETION STUDIES IN VIVO}

\section{Depletion of $\mathrm{CD}^{+}$cells}

$\mathrm{CD}^{+} \mathrm{T}$-cells are the majority of circulating $\mathrm{T}$ cells in DA rats comprising 36.3 (SD 3.4 ) $\%$ of circulating leucocytes in untreated animals (Fig 1A). Monoclonal antibody therapy reduced this to 13.6 (SD 2.8 )\% within a week but further depletion did not occur in the majority of animals, despite continuing antibody treatment, until day 51 when a sudden dramatic decline in cell numbers to 4.9 (SD 1.0)\% occurred (Table 1A). However two animals demonstrated virtually complete depletion of $\mathrm{CD}^{+}$cells by day 14 and double staining demonstrated that most of the circulating $\mathrm{T}$ cells were $\mathrm{CD}^{+}$at this stage. 
A

Day 0

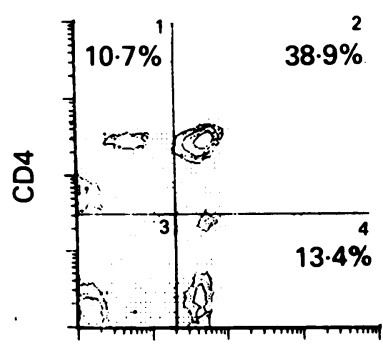

Day 14

Day 51
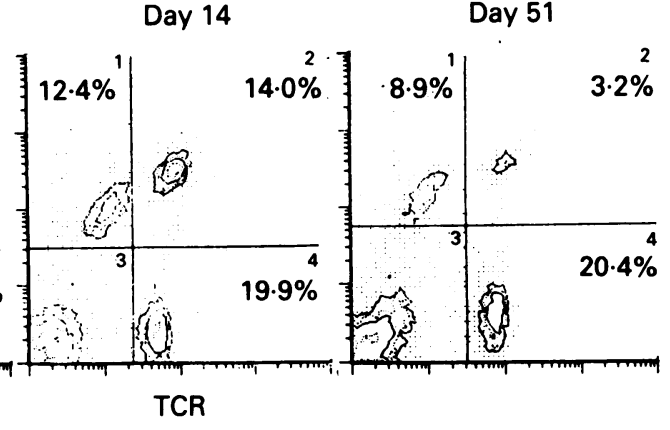

Day 7

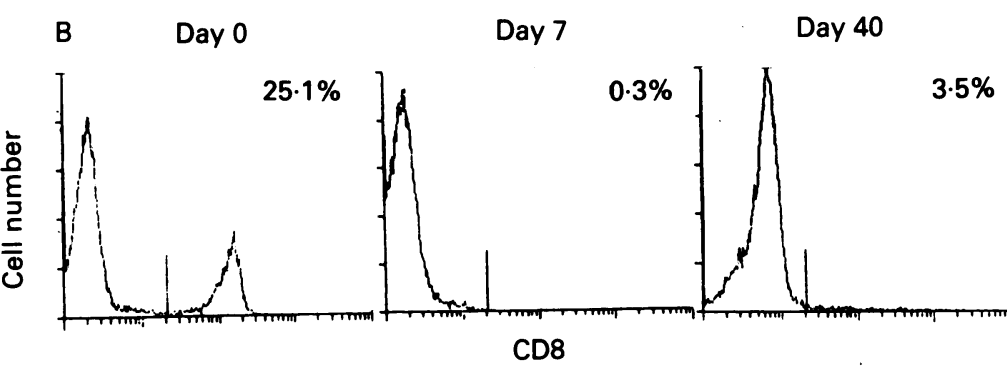

Figure 1 Flow cytometry profiles of peripheral blood leucocytes prepared from a $D A$ rat before treatment (day 0 ) and during treatment with $m A b$ therapy. (A) Flow cytometry profiles of peripheral blood leucocytes of a DA rat double stained for the T-cell receptor, TCR, (with R73 $m A b$, fuorescing green, $x$ axis) and CD4 (with W $3 / 25 \mathrm{mAb}$, fluorescing red, $y$ axis). Four distinct populations of cells were identified on the basis of the intensity of fluorescence, which is proportional to the density of each of the expressed cell surface antigens that were marked. Tcells $(T C R+)$ fluorescing strongly in the green are located in quadrants 2 and $4 . C D 4^{+}$cells fluorescing red are located in quadrants 1 and 2 . The double stained $C D 4^{+} T$-cells are represented in quadrant 2 and comprise $38.9 \%$ of the peripheral blood leucocytes in the untreated rat (day 0 ). Regular $m A$ b therapy depleted the $C D 4^{+} T$-cells to $14 \%$ on day 14 and $3 \cdot 2 \%$ on day 51 . (B) Flow cytometry profiles of leucocytes from a DA rat single stained for CD8 (with $O X 8 \mathrm{mAb}$ ). The number of cells ( $y$ axis) is plotted against the amount of fluorescence on the $x$ axis with a vertical line drawn at the point which no negatively stained cells were found. Thus non-staining cells are to the left of this line and cells staining for CD8 are found to the right, the percentage of these positively staining cells is indicated on the diagram and shows $C D 8^{+}$cells comprising $25 \cdot 1 \%$ of the circulating leucocytes before anti-CD8 treatment (day 0$)$ and almost complete depletion of $C D 8^{+}$cells on days 7 with a small recovery by day 40 .

peripheral blood leucocytes in normal DA rats (Fig 1B). Thrice weekly monoclonal antibody therapy reduced this to $0.7( \pm 0 \cdot 2) \%$ after 1 week, but cell numbers recovered to reach 8.0 (SD 2.9)\% by day 40 despite continuing treatment (Table 1B).

\section{CORNEAL ALLOGRAFT SURVIVAL IN DEPLETED RECIPIENTS}

\section{Untreated allograft recipients}

Of $11 \mathrm{DA}$ rats bearing Lewis allografts three technical failures were excluded from the study. All the remaining eight grafts were rejected between 7 and 21 (median 12) days.

\section{Control $(O X 21)$ treated recipients}

One graft was a technical failure and the animal was killed. The other six rats rejected their Lewis graft between 7 and 21 (median 12) days with no

Table 1 Depletion of $\mathrm{CD4}^{+}$and $\mathrm{CD}^{+}$cells in peripheral blood in $\mathrm{mAb}$ treated, corneal allografted DA rats

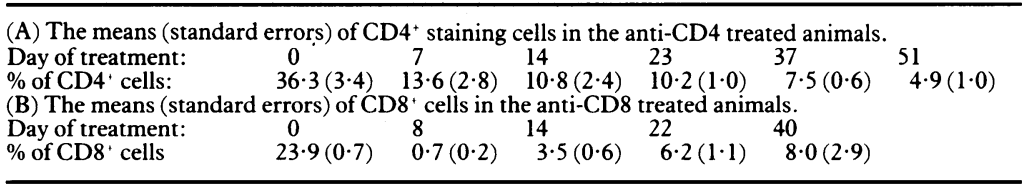

The percentage of blood leucocytes that stained were either CD4 ${ }^{\prime}$ or $\mathrm{CD} 8$ ' is shown against the day of treatment. The day of the first treatment is day 0 and the rats were grafted on day 16 . difference compared to the survival times of grafts in injected recipients (Fig 2A).

\section{Anti-CD8 (OX8) treated recipients}

The six allografts were rejected between 7 and 27 days with a median rejection time of 12 days. There was no difference in the rejection times compared with graft rejection in the OX21 treated controls (Fig 2B).

\section{Anti-CD4 (OX35/OX38) treated recipients}

Six technically successful allografts were followed for 100 days. There was a significant delay in rejection times compared with the OX8 or OX21 treated recipients $(\mathrm{p}<0 \cdot 01$, Mann Whitney test). Four of the grafts were rejected between 13 and 35 (median 22 days) while the remaining two grafts failed to be rejected after 100 days despite cessation of mAb therapy on day 50 (Fig 2C).
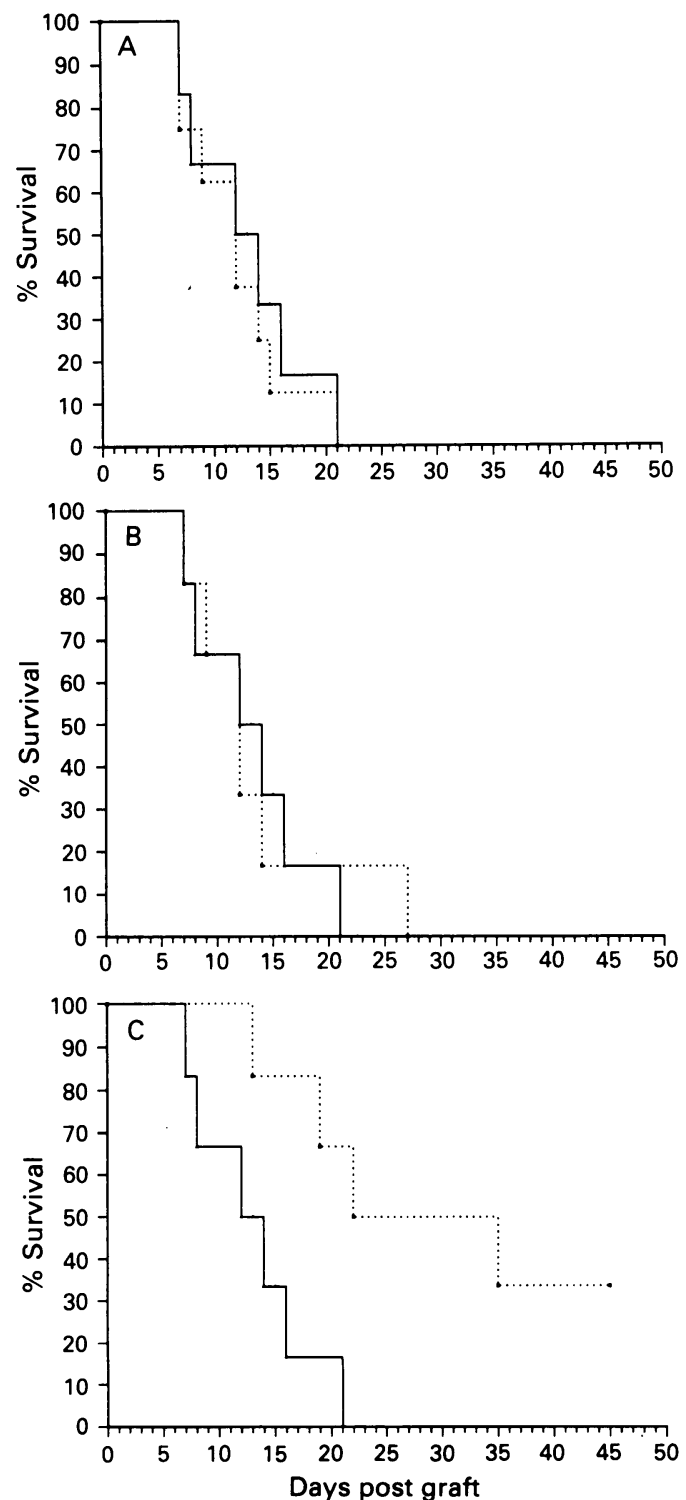

Figure $2(A)$ Survival of allografted corneas in DA rats untreated or treated with non-reactive $m A b O X 21$ (solid line) compared with allografts in untreated control recipients (dotted line). (B) The \% survival of corneal allografts in anti-CD8 treated recipients (dotted line) compared with corneal

allografts in control $(O X 21)$ treated recipients (solid line). $(C)$ The $\%$ survival of corneal allografts in anti-CD4 treated rats (dotted line) compared with allografts in control (OX21) treated recipients (solid line) 
Figure 3 (A)

Vascularised, opaque rejected Lewis corneal allograft in an untreated control $D A$ recipient. $(B) A$ non-rejected long term surviving clear Lewis corneal allograft in a $D A$ recipient depleted of $C D 4$ cells by regular $m A b$ therapy.

\section{Figure 4}

Immunoperoxidase staining with $m A b O X 42$ in a section from the centre of a rejected graft in the anti-CD8 depleted group showing heavy infiltration of macrophages.

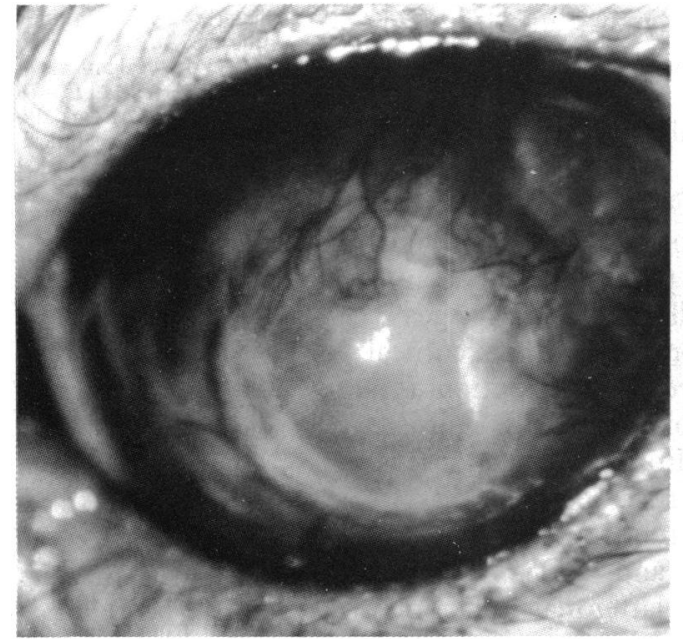

Fig $3 A$

There was no correlation between the amount of $\mathrm{CD}^{+}$cell depletion at the time of grafting and the eventual graft survival.

Rejected allografts became opaque and vascularised and, though after several weeks the opacity partially cleared, the grafts remained vascularised (Fig 3A). In contrast, the long term surviving grafts remained clear and though vessels grew up to the wound they did not grow onto the graft (Fig 3B).

\section{Histology of grafts}

Syngeneic grafts had low numbers of infiltrating leucocytes staining for the leucocyte common antigen CD45 (OX1) and most of these appeared to be macrophages marked by OX42. Rejected grafts in the untreated, $\mathrm{CD}^{+}$depleted, and $\mathrm{CD}^{+}$depleted animals had a heavy infiltration of macrophages staining with OX42 (Fig 4) but all showed low numbers of $\mathrm{T}$-cells and very few $\mathrm{CD} 8\left(\mathrm{OX8}^{+}\right)$cells present. There was a less heavy infiltration of macrophages in rejected grafts from the CD4-depleted animals compared with the untreated controls or CD8-depleted animals.

\section{Discussion}

The mechanism of destruction of allogeneic

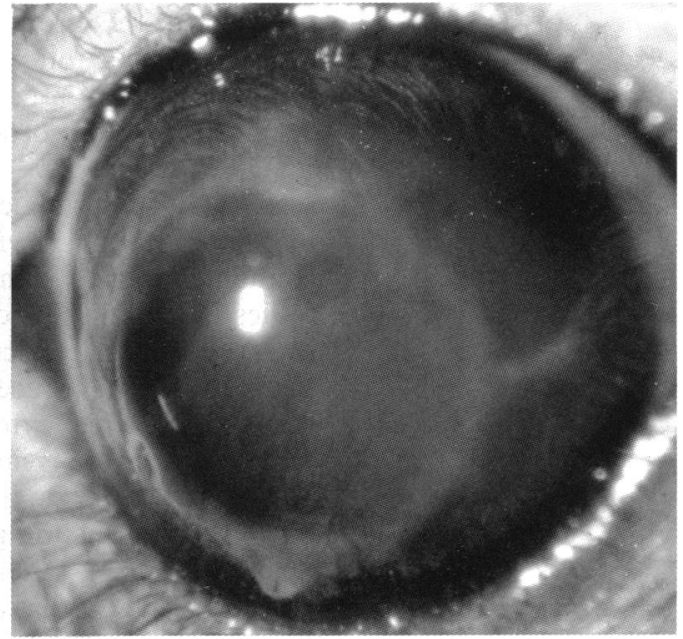

Fig $3 B$

tissue is unknown ${ }^{4}$ and this applies to corneal grafts. Although T-cells are required for the afferent limb of the corneal allograft response, 5 the precise effector mechanism of corneal graft rejection remains an enigma. Using selected $\mathrm{mAbs}$ and frequent administration it was possible to deplete $T$-cell subsets and this enabled an examination of their roles in corneal allograft rejection in vivo.

$\mathrm{CD8}^{+}$cells are important effector cells in immune responses, particularly viral infections and depletion of cells by anti-CD8 $\mathrm{mAbs}$ has been shown to modify the outcome of viral encephalitis. ${ }^{13}$ They have also been presumed to be important in corneal allograft rejection; indeed, in vitro evidence using spleen cells obtained from animals with rejected corneal allografts implicates the cytotoxic $\mathrm{CD}^{+} \mathrm{T}$-cell as the major effector cell. ${ }^{6}$ However the results of the present study suggest that this may not reflect the mechanism of corneal allograft rejection in vivo because animals depleted of $\mathrm{CD}^{+}$cells rejected corneal allografts in the same tempo as controls. This result, although initially surprising, is in fact in keeping with other experimental models where depletion of $\mathrm{CD} 8^{+}$ cells failed to modify allograft rejection in skin and heart allograft models. ${ }^{7617}$ Despite 96$100 \%$ depletion of circulating $\mathrm{CD}^{+}$cells at the time of grafting we also failed to influence corneal graft rejection.

In contrast, results presented in this study show that pretreatment of DA rat recipients for 2 weeks with murine anti-CD4 $\mathrm{mAbs}$ led to significantly prolonged corneal allograft survival or even tolerance.

Depletion of $\mathrm{CD}^{+}$cells is notoriously difficult ${ }^{15}$ and different anti-CD4 mAbs vary in their ability to deplete. The mAb W3/25 reacts with CD4 but fails to deplete, whereas a cocktail of OX35 and OX38 depletes $\mathrm{CD}^{+}$cells very effectively after 6 weeks of treatment..$^{15}$ One difficulty has been that the CD4 molecule is expressed on other cells such as macrophages as well as on T-cells. ${ }^{18}$ In the present investigation the depletion of CD4 T-cells was determined by double staining for CD4 and the alpha-beta TCR. Depletion of $\mathrm{CD}^{+}{ }^{+} \mathrm{T}$-cells from $36 \%$ to $<10 \%$ of peripheral blood lymphocytes correlated with a delayed rejection of corneal 
allografts in this group. It may be that grafting after 6 weeks of treatment when greater depletion of CD4+ cells is obtained may allow better survival of corneal allografts and this is being investigated.

If the $\mathrm{CD} 8{ }^{+}$cytotoxic $\mathrm{T}$-cell is not required for allograft rejection in vivo then several optional candidates remain. The possibilities that antibodies, ${ }^{19}$ natural killer cells, ${ }^{20}$ or macrophages ${ }^{11} 12$ are involved in the effector mechanism of corneal graft rejection have received some attention. It is also possible that cytotoxic $\mathrm{CD}^{+}{ }^{+} \mathrm{T}$-cells are involved but there is no direct evidence for this. Their low numbers in the rejecting corneal grafts and the overwhelming infiltration of macrophages even in $\mathrm{CD}^{+}$and $\mathrm{CD}^{+}$depleted recipients suggest that the latter may in fact play the major role in tissue damage, in a local delayed-type hypersensitivity reaction. ${ }^{21}$ The role of the $\mathrm{CD}^{+} \mathrm{T}$-cells is more likely to be concerned with the recognition of alloantigen presented on antigen presenting cells which explains the specificity of the rejection response. Antigen presentation may occur locally in the limbus and ocular Langerhans cells have been shown to be capable of presenting antigens to T-cells. ${ }^{22}$ Cytokine release by the alloreactive $\mathrm{T}$ cells may activate effector cells, possibly macrophages, locally within the graft leading to graft damage and opacity. Failure to recognise alloantigen in syngeneic grafts or depletion of $\mathrm{CD}^{+}$ cells by $m A b$ does not lead to activation of the effector mechanisms and the corneal grafts remain clear.

As well as increasing understanding of corneal allograft rejection this study suggests that treatment of high risk recipients with anti-CD4 antibodies may have important clinical applications.

We thank the Royal National Institute for the Blind and the North Western Regional Health Authority for grant support for this study.
1 Niederkorn JY. Immune privilege and immune regulation in the eye. Adv Immunol 1990; 48: 191-226.

2 Coster DJ. Mechanisms of corneal graft failure: the erosion of corneal privilege. Eye 1989; 3: 251-62.

3 Khodadoust AA. The allograft reaction: the leading cause of late failure of clinical corneal grafts. Ciba Foundation Symposium 1973; 15: 151-67.

4 Dallman $M$, Morris PJ. The immunology of rejection. In: Morris PJ, ed. Kidney transplantation: principals and practice. Philadelphia: Saunders, 1988: 15-36.

5 Maumenee AE. The influence of donor recipient sensitisation on corneal grafts. Am $\mathcal{F}$ Ophthalmol 1951; 34: 142-52.

6 Peeler JS, Niederkorn JY, Matoba AY. Corneal allografts induce cytotoxic $T$ cell but not delayed type hypersensitivity responses in mice. Invest Ophthalmol Vis Sci 1985; 26: 1516

7 Hall BM, Dorsch S, Roser BJ. The cellular basis of allograft rejection in vivo. $\mathcal{F} E x p M e d$ 1978; 148: 878-89.

8 Dallman MJ, Mason DW, Webb M. The role of host and donor cells in the rejection of skin allografts by $T$ celldeprived rats injected with syngeneic T cells. Eurf Immunol 1982; 12: 511-18.

9 Bolton EM, Gracie JA, Briggs JD, Kampinga J, Bradley JA. Cellular requirements of renal allograft rejection in the Cellular requirements of renal allograft rejection
athymic nude rat. F Exp Med 1989; 169: 1931-46.

10 Whitby EH, Sparshott SM, Bell EB. Allograft rejection in athymic nude rats by transferred T-cell subsets. I. The response of naive $\mathrm{CD} 4^{+}$and $\mathrm{CD} 8^{+}$thoracic duct lymphocytes to complete allogeneic incompatibilities. Immunology 1990 ; to complete

11 Brown R, Ayliffe W, Alam Y, McLeod D, Hutchinson IV The effect of predsol on cells infiltrating rat cornea allografts. Invest Ophthalmol Vis Sci 1991; 32: Suppl 2209.

12 Holland EJ, Chi-Chao Chan, Wetzig P, Palestine AG Nussenblatt RB. Clinical and immunohistologic studies of corneal rejection in the rat penetrating keratoplasty model. Cornea 1991; 5: 374-7.

13 He YuGuang, Ross J, Niederkorn JY. Promotion of murine orthotopic corneal allograft survival by systemic administration of anti-CD4 mAb. Invest Ophthalmol Vis Sci 1991 32: $2723-8$

14 Williams KA, Coster DJ. Penetrating corneal transplantation in the inbred rat: a new model. Invest Ophthalmol Vis $S \mathrm{C}$ 1985; $27: 1199-204$

15 Roser BJ. Cellular mechanisms in neonatal and adult tolerance. Immunol Rev 1989; 107: 179-202.

16 Sedgwick JD. Long term depletion of $\mathrm{CD}^{+} \mathrm{T}$ cells in vivo in the rat. Eur F Immunol 1988; 18: 495-502.

17 Bradley JA, Sarawar SR, Porteous C, Wood PJ, Card S, Ager A, et al. Allograft rejection in CD4 T cell reconstituted A, et al. Allograft rejection in CD4 T cell reconstituted athymic nude rats: the non-essent

18 Jefferies WA, Green JR, Williams AF. Authentic T helper CD4 (W3.25) antigen on rat peritoneal macrophages. $\mathcal{J}$ Exp Med 1985; 162: 117-27.

19 Grunnet N, Kirstensen T, Kissmeyer Neilsen F, Ehlers N. Occurrence of lymphocytotoxic lymphocytes and antibodies after corneal transplantation. Acta Ophthalmol (Kbh) 1976; 54: 167-73

20 Opremcak EM, Whistler RL, Dangle ME. Natural killer cells against the corneal endothelium. Am $\mathcal{F}$ Ophthalmol 1985; 99 524-9.

21 Gebhardt BM. Cell mediated immunity in the cornea Transplantation 1988; 46: 273-80.

22 Williams KA, Ash JK, Mann TS, Coster DJ. Antigenpresenting capabilities of cells infiltrating inflamed corneas. Transplant Proc 1987; 19: 255-6. 